\title{
Perubahan Undang-Undang Dasar Negara Republik Indonesia 1945 Melalui Putusan Mahkamah Konstitusi: Studi Terhadap Putusan Nomor 92/PUU-X/2012
}

\author{
Allan Fatchan Gani Wardhana \\ Mahasiswa Magister Fakultas Hukum Universitas Islam Indonesia \\ Jl.Cik Ditiro No.1 Yogyakarta \\ allanfatchanganiw@yahoo.com
}

\begin{abstract}
After the reform, the amendment of 1945 Constitution of Republic Indonesia, in fact, keeps taking place. The material of 1945 Constitution of Republic Indonesia was amended not only through the formal mechanism of People's Consultative Assembly conventions, but also through informal mechanism or the mechanism outside the formal context, in this case, through the interpretation of the judges of Constitutional Court. This research studied the problems about: first, did the Act of Constitutonal Court Number 92/PUU-X/2012 amend 1945 Constitution of Republic Indonesia? Second, what were the juridical implications of the Acts of Constitution Assembly? The research method used was normative juridical using case study. The result of the research concluded that first, there was an amendment of 1945 Constitution of Republic Indonesia through the Act of Constitutional Court of Republic Indonesia Case Number 92/PUU-X/2012 regarding the process of the formulation and discussion of draft law on Regional Representative Council (DPD) authority. Second, the Act of Constitutional Court had an implication on the position of DPD which is now equal to House of Representatives and President in suggesting draft law and in formulating Prolegnas, DPD must be involved.
\end{abstract}

Key words : Amendment, 1945 Constitution of Republic Indonesia, Act of Constitutional Court

\begin{abstract}
Abstrak
Pasca reformasi perubahan terhadap UUD NRI 1945 ternyata terus berlanjut. Materi UUD NRI 1945 tidak hanya berubah melalui mekanisme formal sidang MPR, namun juga berubah melalui mekanisme informal atau mekanisme di luar ketentuan resmi, dalam hal ini melalui tafsir hakim Mahkamah Konstitusi. Penelitian ini mengkaji permasalahan mengenai, pertama, apakah putusan Mahkamah Konstitusi nomor 92/PUU-X/2012 telah mengubah UUD NRI 1945? Kedua, apa implikasi yuridis atas putusan MK tersebut? Metode penelitian yang digunakan adalah metode yuridis normatif dengan pendekatan kasus. Hasil penelitian menyimpulkan, pertama, adanya perubahan UUD NRI 1945 melalui Putusan MK-RI Nomor Perkara 92/PUU-X/2012 dalam kaitannya dengan proses pembuatan dan pembahasan RUU yang menyangkut dengan kewenangan DPD. Kedua, Putusan MK telah memberikan implikasi yuridis terhadap kedudukan DPD yang kini setara dengan DPR dan Presiden dalam mengusulkan RUU serta penyusunan Prolegnas harus melibatkan DPD.
\end{abstract}

Kata kunci: Perubahan, UUD NRI 1945, Putusan MK. 


\section{Pendahuluan}

Reformasi, mempunyai agenda banyak hal. Perubahan Undang-Undang Dasar Negara Republik Indonesia Tahun 1945 adalah salah satu dari banyak hal. Semangat untuk mengubah atau mengamandemen UUD 1945 membuncah pada waktu reformasi. Sebuah mitos yang menganggap UUD 1945 mengalami “sakralisasi" akhirnya terbantahkan dengan adanya reformasi. Terjadinya reformasi, UUD 1945 yang “disakralkan" mengalami desakralisasi. ${ }^{1}$ Dalam empat kali perubahan itu, materi UUD 1945 yang asli telah mengalami perubahan besar-besaran dan dengan perubahan materi yang dapat dikatakan sangat mendasar. Secara substantif, perubahan yang telah terjadi atas UUD 1945 telah menjadikan konstitusi proklamasi itu menjadi konstitusi yang baru sama sekali, meskipun tetap dinamakan sebagai Undang-Undang Dasar $1945 .{ }^{2}$ Rentang waktu dari 1999 - 2002, perubahan UUD 1945 tersebut dimaksudkan untuk memperbaiki dan menyempurnakan mengenai aturan dasar bernegara yang muaranya adalah membawa perubahan mendasar dalam kehidupan berbangsa dan benegara.

Amandemen sebanyak empat kali secara fundamental telah mengubah aturan dasar berbangsa dan bernegara. Salah satunya ialah penegasan bahwa Indonesia adalah Negara Hukum. Hal tersebut tertuang di dalam Pasal 1 ayat (3) UUD NRI 1945. Negara hukum yang dimaksud adalah negara yang menegakkan supremasi hukum untuk menegakkan kebenaran dan keadilan, dan tidak ada kekuasaan yang tidak dipertanggungjawabkan (akuntabel). Dalam paham negara hukum itu, hukumlah yang memegang komando tertinggi dalam penyelenggaraan negara. Sesungguhnya memimpin dalam penyelenggaraan negara adalah hukum itu sendiri sesuai dengan prinsip the Rule of Law, and not of Man, yang sejalan dengan pengertian nomocratie, yaitu kekuasaan dijalankan oleh hukum, nomos. ${ }^{3}$

Prinsip supremasi hukum yang dianut oleh negara ini, praktis membawa konsekuensi berbagai hal terutama dalam penyelenggaraan kehidupan berbangsa dan bernegara. Dalam perspektif supremasi hukum (supremacy of law), pada hakikatnya pemimpin tertinggi negara yang sesungguhnya bukanlah manusia, tetapi konstitusi yang mencerminkan hukum tertinggi. ${ }^{4}$ Artinya bahwa UUD NRI 1945

${ }^{1}$ Ni'matul Huda, Politik Ketatanegaraan Indonesia Kajian terhadap Dinamika Perubahan UUD 1945, FH UII Press, Yogyakarta, 2004, hlm.3

${ }^{2}$ Jimly Asshiddiqie, Konstitusi dan Konstitusionalisme Indonesia, Sinar Grafika Offset, Jakarta, 2011, hlm. 48

${ }^{3}$ Ibid., hlm. 57

${ }^{4}$ Ibid., hlm.127 
saat ini merupakan pemimpin tertinggi di negara ini. Implikasi dari hal tersebut, UUD NRI 1945 harus menjadi pedoman dalam penyelenggaraan kehidupan berbangsa dan bernegara bagi seluruh warga negara Indonesia. Karena UUD NRI 1945 sebagai pedoman dalam penyelenggaraan kehidupan berbangsa dan bernegara, maka UUD NRI 1945 harus dijaga wibawanya dari segala aspek yang dapat melecehkannya.

Kemudian, muncul lembaga baru - Mahkamah Konstitusi-lembaga peradilan ketatanegaraan yang dimaksudkan untuk menjaga dan mengawal wibawa konstitusi. Keberadaan Mahkamah Konstitusi di Indonesia dilatarbelakangi oleh keinginan untuk menjamin agar UUD NRI 1945 sebagai hukum tertinggi dapat ditegakkan. Karena itu, Mahkamah Konstitusi biasa disebut dengan penjaga konstitusi (the guardians of the constitution). ${ }^{5}$ Pembentukan Mahkamah Konstitusi (MK) adalah sejalan dengan dianutnya paham negara hukum dalam UUD NRI 1945. Dalam negara hukum harus dijaga paham konstitusional. UUD NRI 1945 merupakan puncak dalam tata urutan peraturan perundangan-undangan di Indonesia. Konsekuensi dari itu, tidak boleh ada undang-undang dan peraturan perundangundangan lainnya yang bertentangan dengan UUD NRI 1945.

Kewenangan MK sebagai the guardians of the constitution dapat ditemukan indikasinya dalam Pasal 24C UUD 1945, yaitu bahwa MK berwenang mengadili pada tingkat pertama dan terakhir yang putusannya bersifat final untuk menguji undangundang terhadap undang-undang dasar. Kewenangan yang demikian sering disebut sebagai judicial review, yaitu kewenangan untuk menguji kesahihan produk hukum yang dihasilkan oleh lembaga pembuat undang-undang. Dari kewenangan judicial review tersebut menimbulkan sebuah kewenangan yang mutatis mutandis (dengan sendirinya) ada, yaitu kewenangan menafsirkan konstitusi. ${ }^{6}$ Oleh karena itu, MK juga sering disebut sebagai penafsir konstitusi (the sole interpreter of the constitution). ${ }^{7}$

Kewenangan untuk menafsirkan konstitusi inilah yang kemudian membuka ruang terjadinya interpretasi konstitusi oleh para hakim. Kewenangan tafsir konstitusi yang berasal dari tafsir hakim tersebut memang tidak terlepas dari upaya

${ }^{5}$ MK-RI, Pendidikan Kesadaran Berkonstitusi, Cet-6, Sekretariat Jenderal dan Kepaniteraan Mahkamah Konstitusi Republik Indonesia, Jakarta, 2010, hlm.129

${ }^{6}$ Feri Amsari, Perubahan UUD 1945 Perubahan Konstitusi Negara Kesatuan Republik Indonesia Melalui Putusan Mabkeamah Konstitusi, Cet. 2, Rajawali Pers, Jakarta, 2011, hlm.83

${ }^{7}$ Ni'matul Huda dan R.Nazriyah, Teori \& Pengujian Peraturan Perundang-undangan, Nusa Media, Bandung, 2011, hlm.145 
untuk memenuhi rasa keadilan. Maka dengan kewenangan untuk menafsirkan konstitusi (uji konstitusionalitas) tersebut akan terdapat beberapa kemungkinan, salah satunya adalah perubahan informal terhadap konstitusi. Perkara-perkara uji konstitusionalitas UU terhadap UUD NRI 1945 di MK mengakibatkan terjadinya perubahan UUD NRI 1945. Perubahan tersebut sebagaimana dikemukakan oleh K.C. Wheare, adalah perubahan melalui judicial interpretation atau penafsiran pengadilan. Tentu penafsiran pengadilan yang dimaksud adalah tafsir/interpretasi hakim.

Realitas kasus di Indonesia, pernyataan KC Wheare yang mengemukakan bahwa konstitusi dapat berubah secara informal melalui penafsiran hakim, dapat ditemui dalam putusan Mahkamah Konstitusi No. 92/PUU-X/2012 tentang hasil uji konstitusionalitas produk hukum UU No. 27 Tahun 2009 tentang Majelis Permusyawaratan Rakyat, Dewan Perwakilan Rakyat, Dewan Perwakilan Daerah, dan Dewan Perwakilan Rakyat Daerah (UU MD3) dan UU No. 12 Tahun 2011 tentang Pembentukan Peraturan Perundang-undangan (UU P3).

Berdasarkan Pasal 22D UUD NRI 1945, DPD memiliki kewenangan legislasi diantaranya berupa kewenangan untuk dapat mengajukan Rancangan Undang-Undang dan ikut membahas RUU yang berkaitan dengan bidang-bidang tertentu sebagaimana dimaksud dalam Pasal 22D ayat (1) dan ayat (2) UUD NRI 1945. Kewenangan DPD untuk dapat mengajukan RUU sebagaimana dimaksud dalam Pasal 22D ayat (1) UUD 1945 telah direduksi/ dirugikan dengan berlakunya UU MD3 dan UU P3 tersebut.

Permohonan judicial review yang diajukan oleh Pimpinan DPD dikabulkan oleh MK. Dengan adanya putusan MK Nomor 92/PUU-X/2012 yang mengabulkan sebagian permohonan uji materi tersebut, kini DPD berhak mengajukan rancangan undang-undang (RUU), membahas RUU dalam daftar inventarisasi masalah (DIM), sampai dengan ikut menyusun program legislasi nasional (prolegnas) yang terkait dengan daerah. Mahkamah Konstitusi memutuskan bahwa beberapa ketentuan dalam UU MD3 dan UU P3 dinyatakan bertentangan dengan UUD 1945 dan tidak lagi mempunyai kekuatan hukum mengikat. Dalam putusan tersebut tersinyalir adanya perubahan terhadap UUD NRI 1945.

\section{Rumusan Masalah}

Berdasarkan latar belakang di atas, permasalahan yang menjadi fokus penelitian ini sebagai berikut. Pertama, apakah putusan Mahkamah Konstitusi Nomor 92/PUU- 
X/2012 telah mengubah UUD NRI 1945? Kedua, apa implikasi yuridis atas putusan MK tersebut?

\section{Tujuan Penelitian}

Adapun penelitian ini bertujuan untuk mengetahui: pertama, apakah putusan Mahkamah Konstitusi Nomor 92/PUU-X/2012 telah mengubah UUD NRI 1945; kedua, implikasi yuridis terhadap Putusan Mahkamah Konstitusi Nomor 92/PUUX/2012.

\section{Metode Penelitian}

Jenis Penelitian ini adalah penelitian hukum normatif, karena peneliti melakukan penelitian dengan studi literatur dan peraturan perundang-undangan yang berhubungan dengan objek penelitian guna mencari jawaban atas masalah yang hendak diteliti. Sumber data yang digunakan dalam penelitian ini adalah bahanbahan hukum yang terdiri dari bahan hukum primer, bahan hukum sekunder, dan bahan hukum tersier. Penelitian ini menggunakan teknik pengumpulan bahan hukum melalui metode penelitian library research yang terdiri dari buku-buku, jurnal ilmiah, media massa dan internet serta referensi lain yang relevan. Penelitian ini menggunakan teknik analisis bahan hukum deskriptif kualitatif yaitu pengelompokan dan penyesuaian data-data yang diperoleh dari suatu gambaran sistematis yang didasarkan pada teori dan pengertian hukum yang terdapat dalam ilmu hukum untuk menghasilkan kesimpulan yang signifikan dan ilmiah yang dapat menjawab rumusan masalah penelitian.

\section{Hasil Penelitian dan Pembahasan}

\section{Perubahan Undang Undang Dasar Melalui Tafsir Hakim}

Menurut KC Wheare, ada tiga cara untuk mengubah undang-undang dasar, yaitu : (i) formal amandement atau perubahan resmi, (ii) constitutional convention atau konvensi ketatanegaraan; dan (iii) judicial interpretation atau penafsiran pengadilan. ${ }^{8}$

\footnotetext{
${ }^{8}$ Jimly Asshiddiqie, Pengantar Ilmu Hukum Tata Negara. Cet 3, Rajawali Press, Jakarta, 2011, hlm. 116
} 
Bagi George Jellinek, perubahan konstitusi pada dasarnya dibagi menjadi dua, yaitu; pertama, melalui prosedur formal (verfassungsanderung) dan kedua, melalui caracara informal (verfassungswandlung). Perubahan formal adalah perubahan yang mekanismenya telah diatur di dalam konstitusi suatu negara sedangkan perubahan diluar ketentuan konstitusi disebut sebagai perubahan informal atau melalui kondisi yang disebut Djokosutono secara onbewust (lambat-laun). Walaupun dalam perkembangannya perubahan informal juga dapat memiliki kekuatan hukum mengikat seketika itu juga. ${ }^{9}$ Dalam bahasa Soehardjo Sastrosoehardjo, verfassungsanderung dimaknai sebagai bentuk perubahan yang sesungguhnya, dimana terjadi perubahan terhadap pokok-pokok pikiran, asas-asas, bentuk negara, sistem pemerintahan dan lainnya. ${ }^{10}$ Sedangkan verfassungswandlung menurut Soehardjo adalah perubahan makna ataupun penafsiran ketentuan dalam konstitusi yang tidak menyimpang dari ketentuan pokok serta asas-asas yang termaktub di dalamnya. ${ }^{11}$

Dalam membahas mengenai perubahan konstitusi secara informal, K.C. Wheare $^{12}$ menjelaskan mengenai terdapatnya kekuatan-kekuatan yang mampu menimbulkan perubahan konstitusi itu sendiri. Kekuatan itu sendiri oleh Wheare dibagi menjadi dua, yaitu; pertama, kekuatan yang dapat menciptakan berubahnya kondisi di suatu negara. Kekuatan itu memang tidak merubah kalimat-kalimat dalam konstitusi secara eksplisit, namun kekuatan tersebut mampu menciptakan kondisi yang dapat merubah makna atau kestabilan supremasi konstitusi. Kedua, kekuatan yang mampu menciptakan kondisi sehingga terlaksananya perubahan konstitusi secara formal, melalui interpretasi hakim atau melalui konvensi ataupun kebiasaan ketatanegaraan.

Pandangan wheare ini tentu dilatarbelakangi kasus Marbury vs Madison (1803) pada Supreme Court (MA) Amerika Serikat. Kasus tersebut dalam ilmu hukum khususnya Hukum Tata Negara dipahami sebagai formula awal dari ide perubahan konstitusi melalui penafsiran oleh lembaga peradilan/hakim. ${ }^{13}$ Kewenangan hakim untuk melakukan penafsiran sesungguhnya timbul dari sebuah tafsir pula bahwa tidaklah mungkin dapat melakukan review terhadap sebuah undang-undang agar berkesesuaian dengan konstitusi apabila tidak diberi kewenangan memaknai dan

\footnotetext{
${ }^{9}$ Feri Amsari, Perubaban UUD 1945...,Op Cit., hlm.30

${ }^{10}$ Ibid., hlm.30

${ }^{11}$ Ibid.

${ }^{12}$ K.C. Wheare, Konstitusi-Konstitusi Modern, Nusa Media, Bandung, 2011, hlm.104-184

${ }^{13}$ Feri Amsari, Perubahan UUD 1945...,Op Cit., hlm 5
} 
menafsirkan konstitusi itu sendiri. ${ }^{14}$ Perubahan konstitusi melalui penafsiran hakim ini, menurut Wheare disini hakim tidak melakukan perubahan secara tesktual pada original intent suatu konstitusi, melainkan melalui penafsiran yang mengubah makna dari pasal-pasal (tesktual meaning) dari konstitusi. ${ }^{15}$ Perubahan ini adalah metode perubahan konstitusi dalam arti menambah, mengurangi, atau memperbaiki makna yang terdapat dalam suatu teks konstitusi.

\section{Putusan Mahkamah Konstitusi Nomor 92/PUU-X/2012 Mengubah UUD NRI 1945}

Realitas kasus di Indonesia, pernyataan KC Wheare yang mengemukakan bahwa konstitusi dapat berubah secara informal melalui penafsiran hakim, dapat ditemui dalam putusan Mahkamah Konstitusi Nomor 92/PUU-X/2012 tentang hasil uji konstitusionalitas produk hukum Undang-Undang Nomor 27 Tahun 2009 tentang Majelis Permusyawaratan Rakyat, Dewan Perwakilan Rakyat, Dewan Perwakilan Daerah, dan Dewan Perwakilan Rakyat Daerah (UU MD3) dan Undang-Undang Nomor 12 Tahun 2011 tentang Pembentukan Peraturan Perundang-undangan (UU P3). Pemohon dalam perkara tersebut ialah DPD secara kelembagaan.

DPD merasa bahwa kewenangan konstitusionalnya dirugikan terhadap berlakunya UU MD3 dan UU P3. Permohonan Pengujian Undang-Undang (PUU) terhadap UUD NRI 1945 yang dilakukan oleh DPD ke Mahkamah Konstitusi terdapat lima pokok persoalan konstitusional yang dimohonkan oleh Pemohon, yaitu ${ }^{16}: 1$ ) Kewenangan DPD dalam mengusulkan RUU sebagaimana diatur di dalam Pasal 22D ayat (1) UUD 1945, yang menurut Pemohon, RUU dari DPD harus diperlakukan setara dengan RUU dari Presiden dan DPR; (Sebelum putusan ini dijatuhkan, RUU dari DPD posisinya disamakan dengan usul RUU dari anggota DPR. Antara RUU dan Usul RUU mempunyai implikasi hukum yang berbeda); 2) Kewenangan DPD ikut membahas RUU yang disebutkan dalam Pasal 22D UUD 1945 bersama DPR dan Presiden; 3) Kewenangan DPD memberi persetujuan atas RUU yang disebutkan dalam Pasal 22D UUD 1945; 4) Keterlibatan DPD dalam penyusunan Prolegnas yang menurut Pemohon sama halnya dengan keterlibatan Presiden dan DPR; 5) Kewenangan DPD memberi pertimbangan terhadap RUU yang disebutkan dalam Pasal 22D UUD 1945.

\footnotetext{
${ }^{14}$ Ibid., hlm.84

${ }^{15}$ Ibid., hlm.23

${ }^{16}$ Putusan MK-RI, Nomor Perkara 92/PUU-X/2012, hlm. 239-240
} 
Lima pokok persoalan konstitusional di atas ialah kewenangan DPD yang bersumber dari UUD 1945, akan tetapi ternyata terjabarkan secara bias dalam UU MD3 dan UU P3. Sehingga disinilah kemudian DPD merasa kewenangan konstitusionalnya tereduksi. Putusan Mahkamah Konstitusi terkait hal ini menarik untuk dicermati terutama pada persoalan konstitusional tentang kewenangan DPD untuk ikut membahas RUU. Dalam kaitannya dengan kewenangan DPD untuk membahas RUU, menurut Mahkamah, kewenangan DPD untuk membahas RUU telah diatur dengan tegas dalam Pasal 22D ayat (2) UUD 1945 yang menyatakan : "Dewan Perwakilan Daerah ikut membahas rancangan undang-undang yang berkaitan dengan otonomi daerah; hubungan pusat dan daerah; pembentukan, pemekaran, dan penggabungan daerah; pengelolaan sumber daya alam dan sumber daya ekonomi lainnya, serta perimbangan keuangan pusat dan daerah, serta memberikan pertimbangan kepada Dewan Perwakilan Rakyat atas rancangan undang-undang anggaran pendapatan dan belanja negara dan rancangan undang-undang yang berkaitan dengan pajak, pendidikan dan agama".

Berdasarkan ketentuan tersebut, DPD sebagai lembaga negara mempunyai hak dan/atau kewenangan yang sama dengan DPR dan Presiden dalam membahas RUU yang berkaitan dengan otonomi daerah; hubungan pusat dan daerah; pembentukan, pemekaran, dan penggabungan daerah; pengelolaan sumber daya alam dan sumber daya ekonomi lainnya; serta perimbangan keuangan pusat dan daerah.

Penggunaan frasa "ikut membahas" dalam Pasal 22D ayat (2) UUD 1945 karena Pasal 20 ayat (2) UUD 1945 telah menentukan secara tegas bahwa setiap RUU dibahas oleh DPR dan Presiden untuk mendapat persetujuan bersama. Penggunaan frasa “ikut membahas" adalah wajar karena Pasal 20 ayat (2) UUD 1945 disahkan pada Perubahan Pertama UUD 1945 tahun 1999, sedangkan Pasal 22D UUD 1945 disahkan pada Perubahan Ketiga UUD 1945 pada 2001. ${ }^{17}$ Sehingga konsekuensinya pembahasan RUU yang berkaitan dengan kewenangan DPD harus dilakukan dengan mekanisme tripartit, yaitu DPD, DPR, dan Presiden.

Kemudian MK menjelaskan bahwa "ikut membahas" harus dimaknai DPD ikut membahas RUU yang berkaitan dengan otonomi daerah; hubungan pusat dan daerah; pembentukan, pemekaran, dan penggabungan daerah; pengelolaan sumber daya alam dan sumber daya ekonomi lainnya, serta perimbangan keuangan pusat dan daerah, bersama DPR dan Presiden. Dengan demikian, pembahasan RUU harus

${ }^{17}$ Ibid., hlm. 246 
melibatkan DPD sejak memulai pembahasan pada Tingkat I oleh komisi atau panitia khusus DPR, yaitu sejak menyampaikan pengantar musyawarah, mengajukan, dan membahas Daftar Inventaris Masalah (DIM) serta menyampaikan pendapat mini sebagai tahap akhir dalam pembahasan di Tingkat I. Kemudian DPD menyampaikan pendapat pada pembahasan Tingkat II dalam rapat paripurna DPR sampai dengan sebelum tahap persetujuan.

Menurut Mahkamah, pembahasan RUU dari DPD harus diperlakukan sama dengan RUU dari Presiden dan DPR. Terhadap RUU dari Presiden, Presiden diberikan kesempatan memberikan penjelasan, sedangkan DPR dan DPD memberikan pandangan. Begitu pula terhadap RUU dari DPR, DPR diberikan kesempatan memberikan penjelasan, sedangkan Presiden dan DPD memberikan pandangan. Hal yang sama juga diperlakukan terhadap RUU dari DPD, yaitu DPD diberikan kesempatan memberikan penjelasan, sedangkan DPR dan Presiden memberikan pandangan. Konstruksi UUD 1945 mengenai pembahasan RUU antara Presiden dan DPR, serta DPD (dalam hal terkait RUU tertentu) dilakukan antara lembaga negara, sehingga DIM, diajukan oleh masing-masing lembaga negara, dalam hal ini bagi DPR seharusnya DIM diajukan oleh DPR, bukan DIM diajukan oleh fraksi. ${ }^{18}$

Pasca putusan dijatuhkan, perubahan konstitusi melalui tafsir hakim (dalam hal ini tafsir hakim MK) terjadi dan tidak dapat dihindarkan. Ada dua hal penting yang berkaitan dengan perubahan konstitusi melalui tafsir hakim MK. Pertama, bahwa DPD, DPR, dan Presiden posisinya sejajar dalam membahas RUU yang berkaitan dengan kewenangan DPD. Sejajarnya posisi dalam pembahasan undangundang adalah merujuk pada original intent mengenai perdebatan tentang kewenangan DPD dalam hal membahas RUU tertentu. Putusan terkait hal ini justru menguatkan peran dan kedudukan DPD dalam hal membahas RUU tertentu. Jika dicermati, disejajarkannya DPD dalam membahas RUU bersama dengan DPR dan Presiden didasarkan pada tafsir historis/original intens yang dilakukan oleh hakim MK.

Penganut paham tafsir historis/original intens ini meyakini bahwa keputusan hakim harus didasari pada makna kata-kata atau kalimat yang dipahami melalui analisis sejarah dalam penyusunan dan peratifikasian sebuah hukum atau konstitusi. ${ }^{19}$ Karena itu bagi para hakim yang bermaksud mengetahui makna kata

\footnotetext{
${ }^{18}$ Ibid., hlm. 247

${ }^{19}$ Feri Amsari, Perubahan UUD 1945..., Op. Cit., hlm. 15
} 
atau kalimat dalam ketentuan peraturan, dia harus menafsirkan dengan jalan meneliti sejarah kelahiran pasal tertentu itu dirumuskan. Sejarah yang dimaksud adalah sejarah terjadinya peraturan tertentu dan apa yang merupakan latar belakang, maksud, dan tujuan suatu aturan itu ditetapkan atau dimasukkannya pasal-pasal tertentu ke dalam suatu peraturan. ${ }^{20}$

Sejarah yang berkaitan dengan kewenangan DPD untuk ikut membahas RUU tertentu, dapat ditelusuri dalam pembahasan oleh Panitia Adhoc (PAH ) I yang dilakukan pada Rapat PAH I BP MPR ke-25, 6 September 2001, dengan agenda pembahasan BAB II UUD 1945, satu dari banyak fraksi menyampaikan pandangannya sebagai berikut :

Lukman Hakim Saifuddin dari F-PPP menyampaikan pandangannya terkait kekuasaan legislatif DPD hanya terbatas pada RUU yang berkaitan dengan masalah daerah dan anggaran sebagai berikut.

...kami melihat dari sudut kewenangan dalam konteks legislasi ini, kekuasaan legislatif maka kewenangan baik DPR maupun DPD itu masing-masing memiliki kewenangan dalam mengajukan maupun membahas rancangan undang-undang. Hanya perbedaannya DPD dalam hal mengajukan atau membahas rancangan undang-undang itu dibedakan dengan DPR karena DPD itu hanya sebatas persoalan-persoalan atau rancangan undang-undang yang secara langsung berkaitan dengan daerah. Jadi yang berkaitan dengan daerah atau yang berkaitan dengan anggaran, misalkan itu mereka harus terlibat, mereka memiliki kewenangan untuk mengajukan dan membahas. Tapi tidak seluruh RUU itu kemudian DPD memiliki kewenangan yang sama dengan DPR. Nah, saya pikir ini yang kemudian sekarang ini di antara fraksi-fraksi yang ada akan terpilah atau terpecah menjadi dua pandangan tadi itu dalam melihat hal kekuasaan tadi itu. Oleh karenanya usulan konkrit kami memang strukturnya mungkin perlu di..., seperti usulan Fraksi PDIP itu harus kita tentukan paling tidak minimal menyangkut keanggotaan. Jadi MPR itu apa saja komponennya? Lalu yang kedua bagaimana rekrutmen keanggotaannya? Jadi kami termasuk yang menghendaki bahwa seluruh anggota MPR yang hakekatnya terdiri dari DPR dan DPD itu seluruhnya harus dipilih melalui pemilu. ${ }^{21}$

Kemudian - masih dalam kaitannya dengan sejarah DPD untuk ikut membahas RUU tertentu - pembahasan lebih lanjut tentang Perubahan UUD 1945 dalam ST MPR 2001 dilakukan oleh Komisi A. Pada Rapat Komisi A ke-2 tanggal 5 November

\footnotetext{
${ }^{20}$ Bambang Sutiyoso, Metode Penemuan Hukum, UII Press, Yogyakarta, 2012, Hlm.114-115

${ }^{21}$ Risalah Rapat ke-25 PAH I BP MPR, 6 September 2011, hlm.5 yang dikutip kembali dalam MK-RI, Naskah KomprehensifPerubahan Undang-undang Dasar Negara Republik Indonesia Tahun 1945, Buku III Lembaga Permusyawaratan dan Perwakilan Jilid 2, Sekretariat Jenderal dan Kepaniteraan Mahkamah Konstitusi, 2008, hlm.743

${ }^{22}$ Risalah Rapat Komisi A ke-2 (lanjutan) ST MPR Tahun 2001, tanggal 5 November 2001, hlm.13, Ibid., hlm.761
} 
2001, yang dipimpin Slamet Effendi Yusuf, dilakukan pembahasan DPD berkaitan dengan materi tentang MPR dan tentang Bab DPD itu sendiri.

Amidhan juga menyampaikan dukungannya terhadap Pasal 22C yang mengatur DPD.

...Pasal 22C menurut hemat saya itu sepenuhnya saya dapat menerima. Kemudian Pasal 22D demikian Ayat (1) juga. Tapi menyangkut Ayat (2) saya memilih alternatif kedua, yaitu DPD itu ikut membahas. Tidak cukup hanya mengajukan tapi ikut membahas. Karena dia mendalami masalah-masalah yang penting bagi daerah seperti disebutkan oleh rekan terdahulu menyangkut otonomi daerah, perimbangan pusat dan daerah, sumber daya alam, sumber daya ekonomi, dan lain sebagainya. Tapi tidak usah khawatir. Di sini hanya ikut membahas.Tetapi saya menyarankan tidak perlu diberikan voting right, tidak perlu. Kalau voting right itu biarlah itu memang hak daripada DPR. ${ }^{22}$

Ruben Gobay juga menyampaikan pendapatnya terkait dengan kewenangan legislasi dan pengawasan yang dimiliki DPD, yaitu:

Saya justru di sini sangat menyetujui bahkan saya berpendapat itu amat penting untuk dapat dirumuskan. Pasal 22D ayat (2) alternatif dua, DPD ikut membahas rancangan undang-undang yang berkaitan dengan otonomi daerah, hubungan pusat, daerah dan seterusnya. Kemudian yang kedua, Pasal 3 alternatif dua, DPD dapat melakukan pengawasan atas pelaksanaan undang-undang mengenai otonomi daerah atau seterusnya. ${ }^{23}$

Merujuk dan mengkaji risalah sidang Perubahan UUD 1945, terutama pada sejarah perdebatan mengenai kewenangan DPD dalam membahas RUU tertentu, konsekuensinya frasa "Ikut Membahas" dalam Pasal 22D ayat (2) UUD 1945 harus diartikan sebagai satu kesatuan nafas keterlibatan DPD secara penuh dalam semua proses pembahasan RUU tertentu dengan derajat kewenangan yang sebanding dengan DPR dan Presiden. Frasa "Ikut Membahas" sengaja dirumuskan berdiri sendiri karena Pasal 22D UUD 1945 disahkan pada Perubahan Ketiga UUD 1945. Penggunaan frasa "ikut membahas" adalah wajar karena Pasal 20 ayat (2) UUD 1945 disahkan pada Perubahan Pertama UUD 1945. Oleh karena itu, kedepan memaknai Pasal 22D ayat (2) UUD 1945 haruslah dikaitkan dengan Pasal 20 ayat (2) UUD 1945. Kedua pasal tersebut tidak dapat dipisahkan kaitannya dengan proses pembahasan RUU. Kedua pasal tersebut harus dibaca dan dimaknai menjadi satu kesatuan.

Dalam memaknai kedua pasal tersebut, mengutip Yuliandri, bahwa penafsiran sistematis mesti diberlakukan terhadap istilah dalam pembahasan Rancangan

${ }^{23}$ Ibid., hlm. 764 
Undang-Undang24: Pasal 20 ayat (2) menyatakan, "setiap rancangan undang-undang dibahas oleh DPR dan Presiden untuk mendapatkan persetujuan bersama". Rumusan tersebut menempatkan Presiden dan DPR dalam posisi setara dan sama-sama punya hak untuk membahas Rancangan Undang-Undang. Pada saat bersamaan, Pasal 22D ayat (2) mengatur, "DPD ikut membahas rancangan undang-undang...". Sekalipun dengan menggunakan istilah "ikut membahas", DPD secara prinsip juga berhak untuk ikut membahas Rancangan Undang-Undang. Secara istilah, kata "ikut" dipahami sebagai "menyertai" atau melakukan sesuatu sebagaimana dikerjakan orang lain. Sesuai pengertian tersebut, kata "ikut" tidak dapat dimaknai sebagai sesuatu yang bersifat boleh atau tidak, dimana keikutsertaannya tidak mempengaruhi. Melainkan dimaknai sebagai “hak" DPD untuk ikut dalam pembahasan Rancangan UndangUndang sebagaimana dimaksud Pasal 22D ayat (2). Selain itu, kata "ikut" juga tidak dapat dijadikan alasan untuk mensubordinasi DPD di bawah DPR dalam pembahasan Rancangan Undangundang. Sebab, rumusan Pasal 22D ayat (2) dan Pasal 20 ayat (2) merupakan dua ketentuan yang bersenyawa. Dalam arti, apabila sebuah Rancangan Undang-Undang terkait dengan otonomi daerah, dan lain sebagainya, maka Pasal 20 ayat (2) tidak dapat berdiri sendiri. Melainkan harus bersamaan dan dipersandingkan dengan Pasal 22D ayat (2). Seiring dengan itu, pembahasan sebuah Rancangan Undang-Undang untuk menjadi undang-undang sesuai ketentuan Pasal 20 ayat (2) juga meliputi pembahasan terhadap Rancangan Undang-Undang sebagaimana dimaksud dalam Pasal 22D ayat (1) dan ayat (2). Artinya Rancangan Undang-Undang terkait daerah juga menjadi bagian dari Rancangan Undang-Undang yang mesti dibahas dan disahkan melalui mekanisme yang diatur dalam Pasal 20 ayat (2). Dengan demikian, Pasal 22D ayat (2) yang mengatur keikursertaan DPD dalam pembahasan Rancangan Undang-Undang tidak dapat dipisahkan dari ketentuan Pasal 20 ayat (2). Dalam arti, keikutsertaan DPD dalam pembahasan RUU juga tunduk dan mengacu pada ketentuan Pasal 20 ayat (2).

Senada dengan apa yang dikemukan oleh Yuliandri, dalam memahami konstitusi, Maruarar Siahaan menegaskan dengan membawa "Doctrine of Eclipse": Perubahan UUD 1945 secara bertahap, yang melakukan pergeseran kewenangan legislasi dari Presiden kepada DPR dalam Pasal 20 ayat (1), dihubungkan dengan Pasal 5 ayat (1), yang terjadi dalam perubahan pertama, kemudian telah dilanjutkan

${ }^{24}$ Putusan MK-RI, Nomor Perkara 92/PUU-X...,Op.Cit., hlm. 71 
dengan diadopsinya Pasal 22D tentang DPD dalam perubahan ketiga, yang juga memiliki kewenangan legislasi, sedikit banyak harus juga merubah paradigma kewenangan legislasi DPR dengan memperhitungkan kewenangan DPD. Ketika perubahan UUD terjadi secara bertahap, dan satu konsep atau norma yang dirumuskan dimasukkan ke dalam struktur konstitusi yang sudah terbentuk, maka makna awal yang diberi kepada norma tertentu yang mengandung konsep tertentu, akan menerima pengaruh dari seluruh sistem dalam konstitusi ketika dia memasuki struktur konstitusi. Norma baru harus mengalami harmonisasi dengan keseluruhan struktur dan sistem dalam konstitusi, tetapi sebaliknya juga norma yang sudah ada sebelumnya dalam konstitusi sebelum perubahan, terutama yang berkaitan dengan konsepsi tertentu, akan menerima pengaruh. Dalam hal demikian maka original intent pembentuk/pembaharu, hanya merupakan salah satu jenis pemaknaan, yang tidak dapat digunakan secara berdiri sendiri. Semua perubahan yang terjadi secara bertahap dan dalam waktu yang berbeda, ketika masuk dalam struktur UUD 1945 tanpa analisis dampaknya secara konsepsional, baik terhadap organisasi maupun mekanisme penyelengaraan kekuasaan, dapat menyebabkan rnakna yang diperoleh berdasarkan tafsir yang tekstual individual, menghasilkan norma yang dirumuskan dalam peraturan perundang-undangan yang lebih rendah sebagai penjabaran UUD 1945 tidak konsisten, karena perubahan yang terjadi belakangan tidak memperhitungkan secara optimal dampaknya, baik secara konsepsional maupun struktural. Di India dikenal adanya doctrine of eclipse, yang berbicara tentang dampak perubahan konstitusi pada hukum secara keseluruhan. Perubahan konstitusi yang bertahap juga membawa pengaruh pada konstitusi. Norma-norma yang lebih lama tersebut "...will be regarded as having been 'eclipsed'. Meskipun sesungguhnya doktrin ini dimaksudkan berpengaruh terhadap norma hukum dalam undang-undang hampir mati atau menemui ajal, namun tidak void ab initio. Perubahan UUD yang datang kemudian secara parsial, akan seperti gerhana yang membawa bayangan, sehingga norma hukum dalam Undang-Undang yang dirumuskan sebagai jabaran norma konstitusi yang secara konsepsional dan structural terpengaruh oleh perubahan konstitusi yang terjadi kemudian, akan sangat mungkin bertentangan dengan konstitusi, baik secara parsial maupun secara keseluruhan. Hal tersebut jugalah yang memperkuat kebutuhan mutlak dalam memandang konstitusi sebagai satu struktur yang utuh, sehingga tidak boleh satu pasal tertentu ditafsir secara terpisah lepas dari struktur yang utuh, yang boleh jadi secara gramatikal atau tekstual 
sangat jelas sebagai penafsiran awal yang harus dilakukan, tetapi ketika dilihat secara keseluruhan dalam satu struktur dan sistem konstitusi yang utuh, norma tertentu mengalami pemaknaan tertentu yang berbeda, bahkan terkadang sangat radikal. Merupakan hal yang niscaya jikalau terjadi interdependensi antara teks dengan struktur konstitusi itu sendiri. ${ }^{25}$

Berdasarkan hal tersebut, ke depan dalam memahami dan memaknai konstitusi terutama Pasal 20 ayat (2) UUD 1945 haruslah dikaitkan dengan Pasal 22D ayat (2) UUD. Memahami dan memaknai pasal-pasal tersebut tentu berbasis pada pemahaman bahwa konstitusi adalah sebuah organ dan perlu 'dibaca' secara menyeluruh secara bebas sehingga dapat menjadikan konstitusi sebagai sesuatu yang dapat beradaptasi dengan perubahan zaman. ${ }^{26}$ Adagium yang mendukung hal tersebut adalah "Nemo aliquam partem recte intelligere potest antequam totum perlegit"; tidak seorang pun akan mengerti akan sesuatu sehingga ia membaca seluruh bagiannya. ${ }^{27}$

Kedua, pembahasan RUU yang berkaitan dengan kewenangan DPD haruslah dimaknai bahwa pembahasannya harus melibatkan DPD sejak memulai pembahasan pada Tingkat I oleh komisi atau panitia khusus DPR, yaitu sejak menyampaikan pengantar musyawarah, mengajukan, dan membahas Daftar Inventaris Masalah (DIM) serta menyampaikan pendapat mini sebagai tahap akhir dalam pembahasan di Tingkat I. Kemudian DPD menyampaikan pendapat pada pembahasan Tingkat II dalam rapat paripurna DPR sampai dengan sebelum tahap persetujuan. Jika merujuk pada sejarah/original intent, justru kewenangan untuk melakukan pembahasan pada tingkat I, tingkat II sampai sebelum tahap persetujuan tidak dibahas dalam proses perubahan UUD 1945. Rumusan "ikut membahas" tidak dibatasi pada tahapan apa saja.

Atas kedua hal tersebut di atas, terlepas dari pro-kontra soal isi putusan, sesungguhnya perubahan UUD 1945 secara informal melalui tafsir hakim telah terjadi. Perhatikan tabel di bawah :

\footnotetext{
${ }^{25}$ Ibid., hlm.110-111

${ }^{26}$ Feri Amsari, Perubahan UUD 1945..., Op Cit., hlm.100

${ }^{27}$ Ibid., hlm 117
} 
Tabel

\begin{tabular}{|c|c|}
\hline Sebelum Putusan & Sesudah Putusan \\
\hline $\begin{array}{l}\text { Pasal } 20 \text { ayat (2) UUD } \\
\text { 1945Setiap rancangan } \\
\text { undang-undang dibahas } \\
\text { oleh Dewan Perwakilan } \\
\text { Rakyat dan Presiden } \\
\text { untuk mendapat } \\
\text { persetujuan bersama. }\end{array}$ & $\begin{array}{l}\text { Pasal } 20 \text { ayat (2) UUD 1945Setiap rancangan undang- } \\
\text { undang dibahas oleh Dewan Perwakilan Rakyat dan } \\
\text { Presiden untuk mendapat persetujuan bersama } \\
\text { sedangkan RUU yang berkaitan dengan otonomi daerah; } \\
\text { hubungan pusat dan daerah; pembentukan, pemekaran, dan } \\
\text { penggabungan daerah; pengelolaan sumber daya alam dan } \\
\text { sumber daya ekonomi lainnya; serta perimbangan keuangan } \\
\text { pusat dan daerah pembahasannya melibatkan DPD sejak } \\
\text { memulai pembahasan pada Tingkat I ( pengantar } \\
\text { musyawarah, mengajikan dan membahas DIM serta } \\
\text { penyampaian pendapat mini) oleh komisiatau Pansus DPR } \\
\text { dan menyampaikan pendapat pada Pembahasan Tingkat II } \\
\text { dalam rapat paripurna DPR sampai dengan sebelum tahap } \\
\text { persetujuan. }\end{array}$ \\
\hline $\begin{array}{l}\text { Pasal 22D ayat (2) UUD } \\
\text { 1945Dewan Perwakilan } \\
\text { Daerah ikut membahas } \\
\text { rancangan undang- }\end{array}$ & $\begin{array}{l}\text { Pasal 22D ayat (2) UUD 1945Dewan Perwakilan } \\
\text { Daerah ikut membahas rancangan undang-undang } \\
\text { dimulai sejak pembahasan pada Tingkat I ( pengantar } \\
\text { musyawarah, menyajikan dan membahas DIM serta } \\
\text { penyampaian pendapat mini) oleh komisiatau Pansus DPR } \\
\text { dan menyampaikan pendapat pada Pembahasan Tingkat II } \\
\text { dalam rapat paripurna DPR sampai dengan sebelum tahap } \\
\text { persetujuan yang berkaitan dengan otonomi daerah; } \\
\text { hubungan pusat dan daerah; pembentukan, } \\
\text { pemekaran, dan penggabungan daerah; pengelolaan } \\
\text { sumber daya alam dan sumber daya ekonomi } \\
\text { lainnya, serta perimbangan keuangan pusat dan } \\
\text { daerah; serta memberikan pertimbangan kepada } \\
\text { Dewan Perwakilan Rakyat atas rancangan undang- } \\
\text { undang yang berkaitan dengan pajak, pendidikan dan } \\
\text { agama. }\end{array}$ \\
\hline
\end{tabular}

\section{Implikasi Yuridis Putusan MK-RI Nomor 92/PUU-X/2012}

Denny Indrayana mengemukakan bahwa DPD telah lahir, namun belum sepenuhnya hadir. Keberadaannya hampir sama dengan ketiadaannya. DPD antara (ti)ada dan tiada. Maknanya, dapat dibaca, DPD bisa dianggap antara 'ada' dan 'tiada', atau bahkan DPD berada antara 'tiada' dan 'tiada'. ${ }^{28}$ Lebih lanjut Denny mengatakan bahwa DPD ‘ada’ salah satunya karena legitimasinya yang relatif kuat.

${ }^{28}$ Denny Indrayana, Negara Antara Ada dan Tiada : Reformasi Hukum Ketatanegaraan, Penerbit Kompas, Jakarta, 2008, hlm. 298 
Para anggotanya dipilih langsung melalui sistem pemilu distrik berwakil banyak. Namun, DPD juga 'tiada' karena kuatnya legitimasi hasil pemilu itu tidak berjalan seiring dengan kewenangannya yang cenderung minimalis, terlebih bila dikomparasikan dengan DPR. ${ }^{29}$ Kini, pasca putusan dijatuhkan, selain berimplikasi terhadap perubahan makna yang terkandung di dalam UUD 1945, ternyata juga membawa implikasi yuridis yang positif bagi DPD sebagai lembaga representasi rakyat. Kewenangan DPD dapat dikatakan lebih kuat daripada sebelumnya. Implikasi yuridisnya antara lain: a) terkait dengan kewenangan DPD dalam Pengajuan RUU : Sebelum adanya putusan MK, RUU dari DPD diposisikan sama dengan RUU Usul DPR. Pada kenyataannya, ketentuan di dalam Pasal 147 ayat (1), ayat (3), dan ayat (4) UU MD3 tersebut telah bertentangan dengan Pasal 22D ayat (1) UUD 1945 karena mendistorsi sedemikian rupa RUU yang berasal dari DPD. Menurut ketentuan tersebut, apabila Rapat Paripurna DPR memutuskan memberi persetujuan terhadap usul RUU yang berasal dari DPD, usulan DPD tadi bertransformasi menjadi RUU usul DPR. Pun demikian halnya apabila keputusan Rapat Paripurna adalah “persetujuan dengan pengubahan", maka RUU DPD tersebut juga bertransformasi menjadi RUU usul DPR yang selanjutnya disempurnakan komisi, gabungan komisi, Badan Legislasi, atau panitia khusus DPR.

Pasal 147 ayat (1), ayat (3) dan ayat (4) UU MD3 berbunyi: (1) Pimpinan DPR setelah menerima rancangan undang-undang dari DPD sebagaimana dimaksud dalam Pasal 146 ayat (1) memberitahukan adanya usul Rancangan Undang-Undang tersebut kepada anggota DPR dan membagikannya kepada seluruh anggota DPR dalam rapat paripurna. (3) dalam hal rapat paripurna memutuskan memberi persetujuan terhadap usul Rancangan Undang-Undang yang berasal dari DPD sebagaimana dimaksud pada ayat (2) huruf a, rancangan undang-undang tersebut menjadi Rancangan Undang-Undang usul dari DPR.(4) dalam hal rapat paripurna memutuskan memberi persetujuan dengan pengubahan terhadap usul Rancangan Undang-Undang yang berasal dari DPD sebagaimana dimaksud pada ayat (2) huruf b, rancangan undang-undang tersebut menjadi Rancangan Undang-Undang usul dari DPR dan untuk selanjutnya DPR menugaskan penyempurnaan rancangan undang-undang tersebut kepada komisi, gabungan komisi, Badan Legislasi, atau panitia khusus. Padahal, kewenangan DPD dalam mengajukan RUU tertentu haruslah diterjemahkan kewenangan DPD secara kelembagaan. Ini sesuai dengan

${ }^{29}$ Ibid., hlm. 299 
penafsiran historis dengan mengkaji risalah Perubahan UUD 1945. Saat ini, sesuai dengan putusan MK maka kedudukan DPD dalam mengusulkan RUU setara dengan DPR dan Presiden. Oleh karena itu, harus ada status RUU dari DPD. Ke depan RUU dari DPD hanya boleh dimaknai sebagai RUU yang berasal dari DPD secara kelembagaan. b) terkait Kewenangan DPD dalam pembahasan RUU : Dalam Putusan MK, mekanisme legislasi baru dalam pembahasan RUU dilakukan oleh tiga lembaga (DPR, DPD, dan Presiden). Pembahasan dilakukan dengan mekanisme tripartit jika pembahasan RUU menyangkut RUU yang berkaitan dengan kewenangan DPD. Jika RUU yang tidak berkaitan dengan kewenangan DPD, maka pembahasannya dilakukan antara DPR dan Presiden (bipartit). Sesuai Putusan MK pembahasan baru dapat dimulai jika RUU telah selesai dibahas internal masingmasing lembaga. Dalam konteks ini, tidak ada lagi pembahasan RUU yang terkait dengan kewenangan DPD dalam Pasal 22D UUD 1945 yang melibatkan DPD dan Presiden dengan fraksi-fraksi DPR, artinya dengan pola baru ini pembahasan fraksifraksi di DPR adalah untuk internal DPR, seandainya pembahasan RUU dilakukan dengan pola lama sebelum putusan MK. Secara konstitusional, dengan pola baru yang ditawarkan, putusan MK tidak hanya sebatas memperjelas fungsi legislasi DPD, tetapi juga mengembalikan makna pembahasan bersama yang diatur konstitusi. Dikatakan demikian karena UUD 1945 secara eksplisit menyatakan, pembahasan dilakukan antar-institusi (DPR-DPD-presiden atau DPR-presiden) dan bukan antara fraksi-fraksi DPR dan institusi DPD-presiden. Berdasarkan penjelasan ini, putusan MK mengubah secara fundamental pola pembahasan yang dilakukan selama ini, yaitu dengan memosisikan sama antara fraksi-fraksi DPR dengan presiden dan/atau DPD. Padahal, pandangan fraksi tidak mencerminkan pendapat DPR sebagai institusi. Apalagi, sebagai perpanjangan tangan partai politik, fraksi bukan alat kelengkapan DPR. ${ }^{30}$ UUD 1945 memang jelas merumuskan pembahasan RUU dilakukan melalui mekanisme lembaga (DPR, DPD, dan Presiden). Oleh karena itu, posisi Fraksi dalam pola pembahasan lama yang setara dengan Presiden dan DPD diluruskan oleh MK menjadi bagian internal dari DPR. Dengan pola baru ini, setiap anggota DPR tidak lagi berhadap-hadapan satu sama lain ketika pembahasan dengan DPD dan Presiden, padahal pendapat fraksi tidak mencerminkan pendapat DPR sebagai lembaga. RUU tersebut tidak lagi dibahas dan dilakukan harmonisasi, pembulatan, dan pemantapan konsepsi oleh Badan Legislasi melainkan langsung 
dilakukan pembahasan bersama tripartit (DPD, DPR, dan Presiden).c) kewenangan DPD dalam Perencanaan Program Legislasi Nasional (Prolegnas) : Sesuai Putusan MK, Secara jelas dinyatakan bahwa penyusunan Prolegnas harus melibatkan DPD. Prolegnas sebagai instrumen perencanaan program pembentukan undang-undang merupakan bagian tak terpisahkan dari hak/kewenangan untuk mengajukan RUU yang dimiliki oleh DPD. Apabila DPD tidak terlibat atau tidak ikut serta menentukan Prolegnas, maka sangat mungkin DPD tidak dapat melaksanakan wewenangnya untuk mengajukan RUU sebagaimana dimaksud Pasal 22D ayat (1) UUD 1945, karena dapat saja RUU tersebut tidak menjadi prioritas sehingga tidak akan dibahas. ${ }^{31}$ Oleh karena itu, Prolegnas kedepan akan diusulkan oleh tiga lembaga (DPR, DPD, dan Pemerintah). Tentunya hal tersebut akan mengubah mekanisme yang sudah ada, dimana sebelum adanya Putusan MK, usulan DPD berubah menjadi usulan DPR. d) terkait dengan kewenangan DPD dalam memberikan pertimbangan : Mahkamah Konstitusi menegaskan bahwa ada kewajiban hukum dari DPR dan Presiden untuk meminta pertimbangan DPD atas RUU APBN dan RUU yang berkaitan dengan pajak, pendidikan dan agama.

\section{Penutup}

Berdasarkan analisis dan pembahasan di atas dapat ditarik kesimpulan sebagai berikut. Pertama, Putusan MK-RI No 92/PUU-X/2012 harus diterjemahkan dengan baik dalam kaitannya dengan proses pembuatan dan pembahasan RUU terutama yang menyangkut dengan kewenangan DPD. Di sisi lain putusan tersebut telah mengubah UUD NRI 1945. Perubahan yang dilakukan melalui penafsiran hakim MK tidak melakukan perubahan secara tesktual pada original intent suatu konstitusi, melainkan melalui penafsiran yang mengubah makna dari pasal-pasal (tesktual meaning) dari UUD NRI 1945. Adapun pasal-pasal di dalam UUD NRI 1945 yang maknanya berubah adalah: a) Pasal 20 ayat (2) UUD 1945 yang berbunyi "Setiap rancangan undang-undang dibahas oleh Dewan Perwakilan Rakyat dan Presiden untuk mendapat persetujuan bersama", setelah putusan MK dijatuhkan maknanya telah berubah. Pasal 20 ayat (2) UUD 1945 menjadi bermakna "Setiap rancangan undang-undang dibahas oleh Dewan Perwakilan Rakyat dan Presiden untuk mendapat persetujuan bersama sedangkan RUU yang berkaitan dengan otonomi daerah;

${ }^{31}$ Putusan MK-RI, Nomor Perkara 92/PUU-X...,Op.Cit.,hlm.249 
hubungan pusat dan daerah; pembentukan, pemekaran, dan penggabungan daerah; pengelolaan sumber daya alam dan sumber daya ekonomi lainnya; serta perimbangan keuangan pusat dan daerah pembahasannya melibatkan DPD sejak memulai pembahasan pada Tingkat I ( pengantar musyawarah, mengajikan dan membahas DIM serta penyampaian pendapat mini) oleh komisi atau Pansus DPR dan menyampaikan pendapat pada Pembahasan Tingkat II dalam rapat paripurna DPR sampai dengan sebelum tahap persetujuan." b) Pasal 22D ayat (2) UUD 1945 “Dewan Perwakilan Daerah ikut membahas rancangan undang-undang yang berkaitan dengan otonomi daerah; hubungan pusat dan daerah; pembentukan, pemekaran, dan penggabungan daerah; pengelolaan sumber daya alam dan sumber daya ekonomi lainnya, serta perimbangan keuangan pusat dan daerah; serta memberikan pertimbangan kepada Dewan Perwakilan Rakyat atas rancangan undang-undang yang berkaitan dengan pajak, pendidikan dan agama". Setelah putusan MK dijatuhkan Pasal 22D ayat (2) UUD 1945 menjadi bermakna “Dewan Perwakilan Daerah ikut membahas rancangan undang-undang dimulai sejak pembahasan pada Tingkat I ( pengantar musyawarah, menyajikan dan membahas DIM serta penyampaian pendapat mini) oleh komisi atau Pansus DPR dan menyampaikan pendapat pada Pembahasan Tingkat II dalam rapat paripurna DPR sampai dengan sebelum tahap persetujuan yang berkaitan dengan otonomi daerah; hubungan pusat dan daerah; pembentukan, pemekaran, dan penggabungan daerah; pengelolaan sumber daya alam dan sumber daya ekonomi lainnya, serta perimbangan keuangan pusat dan daerah; serta memberikan pertimbangan kepada Dewan Perwakilan Rakyat atas rancangan undang-undang yang berkaitan dengan pajak, pendidikan dan agama."

Kedua, adanya implikasi yuridis atas Putusan MK-RI Nomor Perkara 92/PUUX/2012. Implikasi yuridis ini terdiri atas empat hal : 1) dalam hal kewenangan pengajuan RUU sebelum adanya putusan MK, RUU dari DPD diposisikan sama dengan RUU Usul DPR. Saat ini, sesuai dengan putusan MK maka kedudukan DPD dalam mengusulkan RUU setara dengan DPR dan Presiden. Oleh karena itu, harus ada status RUU dari DPD. Ke depan RUU dari DPD hanya boleh dimaknai sebagai RUU yang berasal dari DPD secara kelembagaan. 2) dalam hal kewenangan DPD membahas RUU, pasca Putusan MK, mekanisme legislasi baru dalam pembahasan RUU dilakukan oleh tiga lembaga (DPR, DPD, dan Presiden). Pembahasan dilakukan dengan mekanisme tripartit jika pembahasan RUU menyangkut RUU yang berkaitan dengan kewenangan DPD. Jika RUU yang tidak berkaitan dengan kewenangan DPD, maka pembahasannya dilakukan antara DPR dan Presiden (bipartit). 3) dalam hal 
kewenangan DPD merencanakan Program Legislasi Nasional (Prolegnas). Sesuai Putusan MK, Secara jelas dinyatakan bahwa penyusunan Prolegnas harus melibatkan DPD. Prolegnas sebagai instrumen perencanaan program pembentukan undang-undang merupakan bagian tak terpisahkan dari hak/kewenangan untuk mengajukan RUU yang dimiliki oleh DPD. 4) dalam hal kewenangan DPD untuk memberikan pertimbangan, ada kewajiban hukum dari DPR dan Presiden untuk meminta pertimbangan DPD atas RUU APBN dan RUU yang berkaitan dengan pajak, pendidikan dan agama

Untuk itu peneliti memberikan saran, yaitu meskipun pada dasarnya perubahan UUD NRI 1945 dapat dilakukan melalui penafsiran hakim MK, pasal-pasal yang berkaitan dengan DPD tetaplah harus diamandemen secara formal karena dengan melakukan amandemen terhadap UUD 1945 hal tersebut merupakan kunci bagi penguatan eksistensi DPD di parlemen. Perubahan UUD 1945 melalui amandemen formal lebih bertaring daripada perubahan informal melalui penafsiran hakim. Selain itu Putusan MK-RI Nomor Perkara 92/PUU-X/2012 harus diterjemahkan dengan baik dalam kaitannya dengan proses pembuatan dan pembahasan RUU terutama yang menyangkut dengan kewenangan DPD.

\section{Daftar Pustaka}

Amsari, Feri. Perubahan UUD 1945 Perubahan Konstitusi Negara Kesatuan Republik Indonesia Melalui Putusan Mahkamah Konstitusi, Cet2, Rajawali Pers, Jakarta, 2011.

Asshiddiqie, Jimly. Konstitusi dan Konstitusionalisme Indonesia, Sinar Grafika Offset, Jakarta, 2011. , Pengantar Ilmu Hukum Tata Negara, Cet 3, Rajawali Press, Jakarta, 2011.

Huda, Ni'matul. Politik Ketatanegaraan Indonesia Kajian terhadap Dinamika Perubahan UUD 1945, FH UII Press, Yogyakarta, 2004.

Huda, Ni'matul dan R.Nazriyah. Teori E Pengujian Peraturan Perundang-undangan, Nusa Media, Bandung, 2011.

Indrayana, Denny. Negara Antara Ada dan Tiada : Reformasi Hukum Ketatanegaraan, Penerbit Kompas, Jakarta, 2008.

MK-RI. Naskah Komprehensif Perubahan Undang-Undang Dasar Negara Republik Indonesia Tahun 1945, Buku III Lembaga Permusyawaratan dan Perwakilan Jilid 2, Sekretariat Jenderal dan Kepaniteraan Mahkamah Konstitusi, 2008.

Pendidikan Kesadaran Berkonstitusi, Cet6, Sekretariat Jenderal dan Kepaniteraan Mahkamah Konstitusi Republik Indonesia, Jakarta, 2010. 
Sutiyoso, Bambang. Metode Penemuan Hukum, UII Press, Yogyakarta, 2012.

Wheare., K.C., Konstitusi-Konstitusi Modern, Nusa Media, Bandung, 2011.

Undang-undang Dasar Negara Republik Indonesia 1945.

Undang-Undang Nomor 27 Tahun 2009 tentang Majelis Permusyawaratan Rakyat, Dewan Perwakilan Rakyat, Dewan Perwakilan Daerah, dan Dewan Perwakilan Rakyat Daerah .

Undang-undang Nomor 12 Tahun 2011 tentang Pembentukan Peraturan Perundangundangan.

Putusan Mahkamah Konstitusi Nomor 92/PUU-X/2012

http:/ / www.saldiisra.web.id/index.php?option=com_content\&view=article\&id= 542:paradigma-baru-legislasi\&catid=1:artikelkompas\&Itemid=2 , di akses tanggal 22 Oktober 2014. 